\title{
Chemokines and chemokine receptors in CNS pathology
}

\author{
AR Glabinski ${ }^{1}$ and RM Ransohoff ${ }^{2}$ \\ ${ }^{1}$ Department of Neurology, Medical University of Lodz, Szp.im.N.Barlickiego, ul, Kopcinskiego 22, 90-153, Lodz, Poland; \\ ${ }^{2}$ Department of Neurosciences, The Lerner Research Institute, The Cleveland Clinic Foundation, 9500 Euclid Avenue, \\ Cleveland, Ohio 44195, USA
}

\begin{abstract}
Keywords: chemotactic factors; inflammation; central nervous system;
\end{abstract} receptors, chemokine; cell culture

\section{Chemokines, chemokine receptors and CNS pathology-background}

Chemokines are small proinflammatory cytokines which stimulate migration of inflammatory cells in vitro and in vivo. They can be divided according to structure, function and gene localization into four different subfamilies. Chemokines have been ascribed diverse additional functions, including regulation of angiogenesis, control of cell proliferation and developmental tissue patterning.

The suspicion that chemokines could be involved in CNS pathology emerged from considering their target-cell specificity, in light of the selective recruitment of leukocyte populations to the intrathecal compartment in diverse disease processes. Initial studies of chemokine expression in the CNS were performed in models including experimental autoimmune encephalomyelitis (EAE), stroke and meningitis. Early results from these investigations provided the exciting insight that parenchymal CNS cells were among the most abundant sources of chemokines, both in vitro and in vivo. A landmark observation from Karpus et al (1995) was that EAE could be abrogated by passive immunization with antibodies to a single chemokine, MIP- $1 \alpha$.

Chemokine receptors have also found a place in the unique pathologies of the nervous system. Evident relationships between chemokines that function in specific processes and response by appropriate hematogenous receptor-bearing cells have been demonstrated. Of more novelty (if less well understood) has been the finding that chemokine receptors such as CXCR4, CXCR2, CX3CR1 and

Correspondence: M Ransohoff

Received 22 June 1998; revised 31 August 1998; accepted 2 September 1998 the Duffy antigen receptor for chemokines (DARC) are expressed by resident neuroepithelial cells. These varied observations point to a fascinating, diverse and complex array of biological roles for these products in the CNS. Preliminary results in this field are reviewed in this manuscript and summarized in the Tables.

\section{Chemokines in experimental autoimmune encephalomyelitis (EAE)}

EAE is a model of organ-specific autoimmunity, and is a useful experimental system for examining certain aspects of the human disorder multiple sclerosis (MS). The disorder is induced in susceptible animals (mice, rats, guinea pigs or nonhuman primates) with injections of myelin antigens in emulsion. The most common practice at present is to immunize with either whole spinal cord homogenate, myelin protein preparations or peptides derived from myelin proteins. The cardinal encephalitogenic proteins of myelin are myelin basic protein (MBP), myelin proteolipid protein (PLP) and myelin oligodendroglial glycoprotein (MOG).

It has been shown that chemokine upregulation occurs in EAE and correlates with disease appearance (Hulkower et al, 1993; Ransohoff et al, 1993; Godiska et al, 1995; Glabinski et al, 1996a). Godiska and coworkers observed increased expression of mRNA for several chemokines including RANTES, MIP- $1 \alpha$, MIP-1 $\beta$, TCA3, IP-10 MCP-1 KC, and MCP-3 in spinal cord before clinical signs appeared. They reported also that encephalitogenic $\mathrm{T}$ cells expressed transcripts for RANTES, MIP- $1 \alpha$, MIP- $1 \beta$ and TCA3 (Godiska et al, 1995). We observed very transient expression of MCP-1 and IP10 at the beginning of acute EAE (Ransohoff et al, 1993). 
Analysis of chemokine gene expression and histological findings suggested that chemokines amplify but not initiate invasion of CNS by inflammatory cells from the blood (Glabinski et al, 1996a). In situ hybridization showed that several chemokines are expressed by astrocytes in near vicinity of inflammatory cuffs (Ransohoff et al, 1993; Glabinski et al, 1996a; Tani et al, 1996b).

In chronic-relapsing EAE we observed increased expression at the mRNA and protein level of five chemokines (MCP-1, IP-10, MIP-1alpha, GROalpha, RANTES) during spontaneous relapse of the disease (Glabinski et al, 1997). Three of them were expressed by astrocytes (MCP-1, IP-10 and GRO-alpha), two others (MIP-1 alpha and RANTES) by inflammatory cells (Glabinski et al, 1997).

As noted above, Karpus and colleagues provided support for the functional importance of chemokine expression in EAE by passive immunization studies. Anti-MIP- $1 \alpha$ blocked initial attacks of EAE after adoptive transfer of activated antigen-specific T-cells blasts (Karpus et al, 1995). Interestingly, anti-MCP-1 antibodies, which were inert towards initial attacks, significantly reduced relapses of disease, which were unaffected by anti-MIP-1 $\alpha$ (Karpus et al, 1997). These results indicated complex and nonredundant functions of individual $\beta$-chemokines in EAE (Karpus et al, 1998).

\section{Chemokines in nonimmunologic CNS injury}

Shortly after mechanical trauma to the CNS inflammatory cells migrate from the blood to the injury site and begin the process of tissue repair. The cellular signals for that migration are not known. The functions of chemokines suggest that they are attractive candidates for that role. We analzyed four models of CNS trauma: nitrocellulose membrane stab or implant injury to the adult or neonatal cortex. In the models of mechanical injury to the adult brain we observed increased expression of the mRNA for MCP-1 $3 \mathrm{~h}$ after injury (Glabinski et al, 1996b). MCP-1 protein was detected at $12 \mathrm{~h}$ postinjury. In the neonatal stab injury model characterized by lack of inflammation MCP-1 expression was significantly lower than in other models. Other analyzed chemokines (IP-10, MIP-1 $\alpha$, GRO- $\alpha$ ) were not detected at the mRNA or protein level. In situ hybridization experiments combined with immunocytochemistry showed that astrocytes in the vicinity of the injury site were the cellular source of MCP-1 (Glabinski et al, 1996b). Similar kinetics of MCP-1 expression was described in rat models of mechanical injury (Berman et al, 1996). It has been shown also in rat stab wound brain injury that reactive astroyctes may express MIP- $1 \beta$ following trauma (Ghirnikar et al, 1996). After cryogenic lesion to the cerebral cortex MCP-1 mRNA expres- sion peaked at $6 \mathrm{~h}$, remained elevated for $24 \mathrm{~h}$ and then declined by $48 \mathrm{~h}$. IP-10 expression was not upregulated in that brain injury model (Grzybicki et al, 1998). Compatible results were reported by Hausmann and colleagues, who found selective upregulation of MCP-1 expression after sterile but not LPS-augmented cerebral trauma (Hausmann et al, 1998).

There are several reports showing increased expression of some chemokines in experimental models of brain ischemia. This may suggest that locally produced chemokines may stimulate inflammatory cell migration to the ischemic area and contribute to brain injury in ischemic stroke. Kim and coworkers observed increased expression of mRNA for two chemokines (MCP-1 and MIP-1 $\alpha$ ) $6 \mathrm{~h}$ after induction of cerebral ischemia, with peak expression at $24-48 \mathrm{~h}$ (Kim et al, 1995). Immunostaining suggested that MCP-1 positive cells were endothelial cells and macrophages in the ischemic area. The morphology of MIP- $1 \alpha$ positive cells was similar to GFAP-positive astrocytes (Kim et al, 1995). Contradictory results were published by others who showed by double in situ hybridization that MIP- $1 \alpha$ is produced by Mac- 1 positive microglial cells with peak of expression $4-6 \mathrm{~h}$ after onset of occlusion (Takami et al, 1997). Increased MCP-1 mRNA expression at $6 \mathrm{~h}$ after occlusion of middle cerebral artery (MCAO) has also been reported. The kinetics of MCP-1 expression was similar after permanent MCAO or MCAO reperfusion (Wang et al, 1995).

Astrocytes were the cellular source of MCP-1 from $6 \mathrm{~h}$ to 2 days after MCAO, as reported by Gourmala et al (1997). At later time points MCP-1 was detected in macrophages and reactive microglia in the ischemic area (Gourmala et al, 1997). Increased MCP-1 expression has been observed as early as $1 \mathrm{~h}$ after reperfusion in the rat forebrain reperfusion model (Yoshimoto et al, 1997). Chemokine CINC (cytokine-induced neutrophil chemoattractant) which belongs to IL-8 family and is a potent neutrophil chemoattractant in rats, was overexpressed in the cerebral cortex of rats 6$12 \mathrm{~h}$ after MCAO (Liu et al, 1993). Another group observed increased CINC expression in the brain and serum 3-12 h after reperfusion. One hour of ischemia without reperfusion did not produce increase in CINC expression in the brain (Yamasaki et al, 1995).

\section{Expression of chemokines in the CNS of transgenic mice}

Most of the early information about chemokines and their physiological roles came from in vitro studies. Those results could not be directly extrapolated to the in vivo situation. This problem has been addressed by the demonstration that pro- 
grammed expression of chemokine genes in the CNS can trigger the recruitment of leukocytes in vivo (Lira et al, 1997). MCP-1 transgene expressed in oligodendrocytes under control of MBP promoter was able to induce accumulation of inflammatory cells within the CNS (Fuentes et al, 1995). Immunohistochemical staining showed that infiltrating cells were monocytes/macrophages and they were localized mainly in perivascular areas with minimal parenchymal infiltration. MCP-1 immunoreactivity was detected at the abluminal surface of cerebral microvessels. The mononuclear cell accumulation was massively amplified at that model by intraparenchymal injection of lipopolysaccharide (LPS). Despite monocyte accumulation no neurological or behavioral signs were observed (Fuentes et al, 1995).

CNS-specific expression of $\alpha$-chemokine KC, which is a potent neutrophil chemoattractant in vitro produced impressive neutrophil infiltration into perivascular, meningeal and parenchymal CNS sites (Tani et al, 1996a). KC expression was detected in oligodendrocytes and colocalized with infiltrating neutrophils. Three weeks old mice were healthy and behaviorally normal despite remarkable neutrophil accumulation. Beginning at 40 days of age MBP-KC mice developed a neurological syndrome of pronounced postural instability and rigidity. The major neuropathological findings at that time were microglial activation and blood-brain barrier disruption (Tani et al, 1996a). Results obtained from these experiments suggested that chemokines are potent inducers of inflammatory cell migration into the CNS in vivo. Moreover, their activities were target cell-specific in vivo and restricted mainly to triggering migration but not activation (Ransohoff et al, 1996).

\section{Chemokines in human CNS pathology}

Migration of inflammatory cells from the blood to the CNS compartment is the principal pathological feature of bacterial meningitis. Most information about chemokine involvement in human CNS pathology comes from studies analyzing chemokine levels in the CSF of patients with meningitis. Spanaus and collaborators analyzed by ELISA concentrations of several chemokines in the CSF of patients with pyogenic meningitis (Spanaus et al, 1997). They found significantly increased levels of IL-8, GRO- $\alpha$, MIP- $1 \alpha$, and MIP- $1 \beta$ but not RANTES, when compared with noninflammatory CSF controls. The CSF from meningitis patients was chemotactic in vitro for neutrophils and mononuclear leukocytes and the migration was diminished by specific anti-chemokine antibodies (Spanaus et al, 1997). In another study elevated levels of IL-8, GRO- $\alpha$ and MCP-1 were found in the CSF from patients with bacterial and aseptic meningitis but not in parallel blood serum specimens (Sprenger et al, 1996). Number of granulocytes in the CSF from bacterial meningitis patients correlated with IL-8 and GRO- $\alpha$ levels, whereas MCP-1 level correlated well with mononuclear cell count in aseptic meningitis (Sprenger et al, 1996). In another study IL-8 concentration in the CSF was higher than $2.5 \mathrm{ng} / \mathrm{ml}$ in all samples from patients with pyogenic meningitis, but also in some samples from patients with nonbacterial meningitis (LopezCortes et al, 1995). In patients with nonpyogenic meningitis a significant correlation between IL-8 levels and CSF granulocyte counts was found (Lopez-Cortes et al, 1995). These results suggest that chemokines are involved in inflammatory cell accumulation in the subarachnoid space.

MIP- $1 \alpha$ in the CSF was reported to be increased in multiple sclerosis patients during relapse as well as in CSF from patients with Behcet's disease and HTLV-1 associated myelopathy. MIP- $1 \alpha$ level in that study correlated with leukocyte and protein concentration in the CSF (Miyagishi et al, 1995). Increased level of IL-8 was also detected in CSF of patients with severe brain trauma, at higher levels in CSF than in corresponding serum and correlated directly with blood-brain barrier dysfunction (Kossmann et al, 1997).

There is little information about cellular sources of chemokine production during human CNS pathology. MCP-1 immunoreactivity was detected in reactive microglia and mature but not in immature senile plaques in autopsy specimens from five Alzheimer disease patients (Ishizuka et al, 1997). Simpson and coworkers demonstrated expression of MCP-1 protein by astrocytes bordering active MS lesions, compatible with prior observations in EAE, trauma and cerebral ischemia models (Simpson et al, 1998). Hvas et al showed that RANTES mRNA was expressed by perivascular inflammatory cells in MS brain sections as previously reported in EAE (Hvas et al, 1997).

\section{Chemokine expression by CNS cells in vitro}

MCP-1 was originally purified in 1989 from the culture supernatant of a glioma cell line (Yoshimura et al, 1989). Since that time numerous studies on chemokine expression by CNS cells in vitro have been published. Many human glioma cell lines were shown to produce IL-8 and MCP-1, while none of neuroblastoma cell lines expressed these cytokines (Morita et al, 1993). In other studies IL-8 was produced by five astrocytoma cell lines (Nitta et al, 1992) and also in some glioblastoma cell lines (Kasahara et al, 1991). Cultured astroyctes stimulated by cytokines $\mathrm{TNF} \alpha$ and $\mathrm{TGF} \beta$ express MCP$1 \mathrm{mRNA}$ and protein (Hurwitz et al, 1995). IFN $\gamma$ can also stimulate MCP-1 expression by astrocytoma cell line (Zhou et al, 1998). Additionally, stimulated 
astrocytes can express MIP- $1 \alpha$ and MIP-1 $\beta$ (Peterson et al, 1997) and RANTES (Barnes et al, 1996). LPS, IL-1 $\beta$ and TNF- $\alpha$ stimulate production of MCP-1 by astrocytes but not microglia (Hayashi et al, 1995). HIV-1 transactivator protein Tat significantly increase astrocyte production of MCP-1, but not RANTES, MIP- $1 \alpha$ and MIP-1 $\beta$ suggesting that HIV may induce monocyte infiltration in the CNS via astrocyte stimulation (Conant et al, 1998). IP-10 and RANTES expression can be upregulated in primary rat astrocytes and microglia by the infection of neurotropic paramyxovirus NDV (Fisher et al, 1995). Beta amyloid peptide is able to stimulate expression of IL-8 by human astrocytoma cells (Gitter et al, 1995).

Microglial cells are critical for CNS response to varied forms of injury. When stimulated in vitro by LPS, IL-1 $\beta$ and TNF $\alpha$ they can produce IL-8. Pretreatment with IL-4, IL-10 or TGF-beta 1 inhibited the stimulatory effects of these proinflammatory cytokines (Ehrlich et al, 1998). Cryptococcal polysaccharide was also capable of inducing IL-8 production by human fetal microglial cells showing that some fungi can stimulate endogenous CNS cells to express chemokines (Lipovsky et al, 1998).

Human cultured microglia produce MIP-1 $\alpha$, MIP$1 \beta$ and MCP-1 in response to LPS, TNF $\alpha$ or IL- $1 \beta$ (McManus et al, 1998). Moreover MCP-1 expression by brain macrophages can be also stimulated by IL-6 and CSF-1 (Calvo et al, 1996) as well as the active fragment of beta amyloid (Meda et al, 1996). This last observation gives new insight into mechanisms underlying amyloid plaque formation in the CNS during Alzheimer disease. Microglial cells infected by SIV in vitro can produce more IL-8 than uninfected cultures (Sopper et al, 1996).

$\mathrm{TNF} \alpha$ treatment of mixed human brain cell cultures stimulated higher expression of RANTES and MIP-1 $\beta$ than observed after similar stimulation of microglial cells (Lokensgard et al, 1997). Cultured brain endothelial cells were shown to express mRNA for MCP-1. Treatment with TNF $\alpha$ increased MCP-1 expression in a dose-dependent manner (Zach et al, 1997). Bovine brain microvessel endothelial cells showed increased expression of IL-8 after infection with bacterial parasite $C$. ruminantium (Bourdoulous et al, 1995).

\section{Chemokine receptors - overview}

Chemokines act on target cells via seven-transmembrane-domain receptors that signal through GTPbinding proteins. Two main subgroups of chemokine receptors have been described: CXC chemokine receptors (CXCR) with $36-77 \%$ and CC chemokine receptors (CCR) with 46-89\% identical amino acids (Baggiolini et al, 1997). Lately a receptor for $\mathrm{CX}_{3} \mathrm{C}$ chemokine-fractalkine/neurotactin was identified (Imai et al, 1997), so far there is no known receptor for $\mathrm{C}$ chemokine lymphotactin. The largest family of chemokine receptors are CCR receptors consisted of ten receptor types in human (CCR1-CCR10). CXCR receptor family includes four types of receptors in humans (CXCR1CXCR5). Chemokine receptors can be categorized into four different subgroups: shared, specific, promiscuous and viral (Premack and Schall, 1996). Most of the chemokine receptors can bind more than one chemokine ligand belonging to the same chemokine subfamily (shared group). CXCR2 binds several CXC chemokines that contain a canonical glutamate-leucine-arginine (ELR) motif. CXCR3 binds non-ELR CXC chemokines including $\beta$-R1/I-TAC (Cole et al, 1998; Rani et al, 1996), IP-10 and Mig. All CCR receptors have several ligands. There is a promiscuous chemokine receptor designated as DARC which is identical to Duffy blood group antigen on erythrocytes. It binds chemokines from CC and CXC subfamilies and it is postulated that it works in the blood as a 'sink' for chemokines because of the lack of signaling. Two (among several other) viruses encode chemokine receptors: Cytomegalovirus (CMV US28) and Herpes virus saimiri (HSV ECRF3) (Murphy, 1996; Premack and Schall, 1996). The role of virally encoded chemokine receptors is unknown but preservation of signaling function is of considerable interest (Murphy, 1996).

\section{Chemokine receptors in CNS pathology}

Expression of several different chemokine receptors has been detected in the normal CNS as well as in cultured cells derived from CNS components (Tables 1 and 2). The fractalkine receptor CX3CR1 was detected at surprisingly high levels in normal brain and spinal cord in both human and rodent specimens before its response to the fractalkine ligand was described (Combadiere et al, 1995; Harrison et al, 1994; Imai et al, 1997). Fractalkine was also demonstrated to be highly abundant in normal CNS tissues and upregulated in pathology, suggesting important functions for this ligandreceptor system in neural physilogy (Bazan et al, 1997; Pan et al, 1997). Horuk and coworkers detected the DARC receptor on cerebellar Purkinje cells in archival human brain sections (Horuk et al, 1996) and CXCR-2 on projection nuerons in diverse regions of the brain and spinal cord (Horuk et al, 1997). The same group reported detection of chemokine receptors CCR1, CCR5, CXCR2 and CXCR4 by immunohistochemistry in cultured human neurons (Hesselgesser et al, 1997). Transcripts for CXCR4 were identified also by Northern blot (Heesen et al, 1996a; Nagasawa et al, 1996) and RT-PCR (Heesen et al, 1997) in cultured primary mouse astrocytes. Cultured astrocytes were shown to express also CCR1 (Tanabe et al, 1997), but not 
CCR2 and CXCR2 (Heesen et al, 1996b). Other studies confirmed that CXCR4 is expressed by microglia in human and mouse brain (He et al, 1996). The single unequivocal demonstration that chemokine receptors are important for developmental neural patterning comes from the finding that CXCR4 knockout mice exhibit abnormal formation of the CNS (Littman, 1998). Two alternatively spliced forms of mouse CXCR4 have been identified both of which are expressed by cultured astrocytes and microglia (Heesen et al, 1997). Several orphan chemokine receptor-like proteins were detected in the CNS. They have structure similar to chemokine receptors but their ligands

Table 1a Chemokines upregulated in experimental infectious CNS pathology

\begin{tabular}{|c|c|c|c|c|}
\hline Upregulated chemokine & CNS pathology & Animal & Cellular source & Reference \\
\hline $\begin{array}{l}\text { MIP- } 1 \alpha, \text { MIP- } 1 \beta \text {, RANTES, } \\
\text { MCP-3, IP-10 }\end{array}$ & $\begin{array}{l}\text { SIV-induced AID, } \\
\text { encephalitis }\end{array}$ & Monkey & $\begin{array}{l}\text { Endothelial cells, } \\
\text { Monocytes, Microglia }\end{array}$ & Sasseville et al, 1996 \\
\hline $\begin{array}{l}\text { IP-10, RANTES, MCP-1, } \\
\text { MIP-1 } \beta \text {, MCP-3, } \\
\text { Lymphotactin, C10, } \\
\text { MIP-2, MIP-1 } \alpha\end{array}$ & $\begin{array}{l}\text { Lymphocytic, } \\
\text { Chorio-meningitis }\end{array}$ & Mouse & Brain homogenate & Asensio and Campbell, 1997 \\
\hline MIP-1 $\alpha$, MIP-2 & $\begin{array}{l}\text { Listeria meningo- } \\
\text { encephalitis }\end{array}$ & Mouse & $\begin{array}{l}\text { Granulocytes, } \\
\text { Monocytes }\end{array}$ & Seebach et al, 1995 \\
\hline $\begin{array}{l}\text { IP-10, RANTES, MCP-1, } \\
\text { MCP-3, MIP-1 } \beta, \text { MIP-2 }\end{array}$ & $\begin{array}{l}\text { Hepatitis virus } \\
\text { encephalomyelitis }\end{array}$ & Mouse & Astrocytes & Lane et al, 1998 \\
\hline
\end{tabular}

Table 1b. Chemokines upregulated in experimental noninfectious CNS pathology

MCP-1, RANTES, MIP- $1 \alpha$, MIP- $1 \beta$, TCA-3, IP-10, MCP-1, KC, MCP-3,

Fractalkine

MCP-1, MIP- $1 \alpha$, MIP- $1 \beta$

MCP-1

MCP-1

MCP-1, MIP-1 $\alpha$, CINC

\section{EAE, ChREAE}

Mouse, Rat

\section{Freeze injury} Chemical injury

Brain ischemia

\section{Rat}

CNS, homogenate astrocytes, microglia, lymphcytes, macrophages, endothelial cells

\section{Mouse, Astrocytes,}

Rat macrophages, endothelial cells, microglia

Homogenate

Astrocytes, macrophages

Brain homogenate, endothelial cells microglia, macrophages, astrocytes
Hulkower et al, 1993; Ransohoff et al, 1993; Godiska et al, 1995; Glabinski et al, 1996; Karpus et al, 1995; Tani et al, 1996; Pan et al, 1997; Glabinski et al, 1997; Berman et al, 1996; Miyagishi et al, 1995

Glabinski et al, 1996; Berman et al, 1996; Ghirnikar et al, 1996; Hausmann et al, 1998; McTigue et al, 1998; (JNR in press)

Grzybicki et al, 1998

Calvo et al, 1996; Hausmann et al, 1998; McTigue et al, 1998; (JNR in press)

Wang et al, 1995; Lu et al, 1993; Yamasaki et al, 1995; Kim et al, 1995; Takami et al, 1997; Gourmaia et al, 1997; Ivacko et al, 1997

Table 2 Chemokines upregulated in human CNS pathology

\begin{tabular}{|c|c|c|c|}
\hline Upregulated chemokine & CNS pathology & Tissue source & Reference \\
\hline IL-8 & Astrocytoma, glioblastoma & Tumor cells & Van Meir et al, 1992; Nitta et al, 1992 \\
\hline IL-8, Gro- $\alpha$, MCP-1, MIP- $1 \alpha$, MIP- $1 \beta$ & Bacterial and aseptic meningitis & & $\begin{array}{l}\text { Sprenger et al, 1996; Spanaus et al, 1997; } \\
\text { Lopez-Cortes et al, } 1995\end{array}$ \\
\hline MIP- $1 \alpha$ & $\begin{array}{l}\text { Multiple sclerosis, } \\
\text { Behcet's disease, } \\
\text { HTLV-1, myelopathy }\end{array}$ & & Miyagishi et al, 1995 \\
\hline IL-8 & Brain injury & & Kossman et al, 1997 \\
\hline MCP-1 & HIV-1 associated dementia & & Conant et al, 1998 \\
\hline MCP-1 & Alzheimer disease & $\begin{array}{l}\text { Microglia, } \\
\text { senile plaques }\end{array}$ & $\begin{array}{l}\text { Ishizuka et al, 1997; Hvas et al, 1997; } \\
\text { Simpson et al, } 1998\end{array}$ \\
\hline RANTES & Multiple sclerosis & $\begin{array}{l}\text { Perivascular } \\
\text { leukocytes }\end{array}$ & Hvas et al, 1997 \\
\hline MCP-1 & Multiple sclerosis & Astrocytes & Simpson et al, 1998 \\
\hline
\end{tabular}


have not been identified so far. One of them is CXCR5 receptor isolated initially from Burkitt's lymphoma cells but expressed also in mature B cells and in brain neurons (Kaiser et al, 1993).
Another example of orphan chemokine-like receptors in a family of LCR-1 receptors identified initially in bovine locus coeruleus, later rat and sheep homologs were found (Wong et al, 1996).

Table 3 Chemokines expressed by cultured cells

\begin{tabular}{|c|c|c|c|}
\hline Chemokine & CNS cells & Species & Reference \\
\hline MCP-1, IL-8 & $\begin{array}{l}\text { Glioma, astrocytoma, } \\
\text { glioblastoma }\end{array}$ & Human & $\begin{array}{l}\text { Morita et al, 1993; Van Meir et al, 1992; } \\
\text { Nitta et al, 1992; Kasahara et al, 1991; } \\
\text { Zhou et al, 1997 }\end{array}$ \\
\hline $\begin{array}{l}\text { MCP-1, IL-8, MIP-1 } \alpha, \text { MIP-1 } \beta \text {, } \\
\text { RANTES, IP-10 }\end{array}$ & Activated astrocytes & Human, rat murine & $\begin{array}{l}\text { Gitter et al, 1995; Peterson et al, 1997; } \\
\text { Conant et al, 1993; Barnes et al, 1996; } \\
\text { Sun et al, 1997; Hurwitz et al, 1995; } \\
\text { Fisher et al, 1995; Hayashi et al, } 1995\end{array}$ \\
\hline $\begin{array}{l}\text { MIP-1 } \alpha, \text { MIP-1 } \beta, \text { MCP-1, IL-8, } \\
\text { RANTES, IP-10 }\end{array}$ & $\begin{array}{l}\text { Activated microglia, brain } \\
\text { macrophages }\end{array}$ & $\begin{array}{l}\text { Human simian rat } \\
\text { murine }\end{array}$ & $\begin{array}{l}\text { McManus et al, 1998; Peterson et al, } \\
\text { 1997; Ehrlich et al, 1998; Lipovsky et al, } \\
\text { 1998; Lokensgard et al, 1997; Sopper et } \\
\text { al, 1996; Sun et al, 1997; Hurwitz et al, } \\
\text { 1995; Fisher et al, 1995; Hayashi et al, } \\
\text { 1995; Meda et al, 1996; Calvo et al, } 1996\end{array}$ \\
\hline MCP-1, IL-8 & Stimulated cerebral endothelium & $\begin{array}{l}\text { Human, bovine, } \\
\text { porcine, murine }\end{array}$ & $\begin{array}{l}\text { Zach et al, 1997; Lou et al, 1997; } \\
\text { Bourdoulous et al, 1995 }\end{array}$ \\
\hline RANTES & Infected neurons & Mouse & Halford et al, 1996 \\
\hline RANTES, MIP-1 $\alpha$ & Mixed brain cell cultures & Human & Lokensgard et al, 1997 \\
\hline
\end{tabular}

Table 4 Chemokine receptors detected in normal CNS in vivo

\begin{tabular}{llll}
\hline Receptor & Localization & Species & Reference \\
\hline CXCR-2 & Projection neurons & Human autopsy brain & Horuk et al, 1997; Xia et al, 1997 \\
DARC & Purkinje cells & Human autopsy brain & Horuk et al, 1996 \\
CCR-3 & Microglia & Human autopsy brain & He et al, 1996 \\
CXC $_{3}$ CR-1 & & Human brain RNA & Combadiere et al, 1995; Harrison et al, 1994 \\
CCR-3, CCR-5, CXCR4 & Pyramidal neurons, glial cells & Macaque & Westmoreland et al, 1998 \\
RLCR-1 & Neurons, ependymal cells & Rat & Wong et al, 1996 \\
CCR-5 & Normal brain & Rat & Jiang et al, 1998 \\
CXCR5 & Granule and Purkinje cell layer & Mouse & Kaiser et al, 1993 \\
\hline
\end{tabular}

Table 5 Chemokine receptors upregulated in CNS pathology

\begin{tabular}{|c|c|c|c|}
\hline Upregulated receptor & CNS disease & Cellular source & Reference \\
\hline CXCR-2, CCR3 & Alzheimer disease & Neurons & Horuk et al, 1997; Xia et al, 1997; He et al, 1996 \\
\hline CCR3, CCR5, CXCR53, CXCR4 & SIV encephalomyelitis & Perivascular infiltrates & Westmoreland et al, 1998 \\
\hline CCR2, CCR5, CXCR4, CX 3 CR1 & EAE & Spinal cord homogenate & Jiang et al, 1998 \\
\hline
\end{tabular}

Table 6 Chemokine receptors expressed by cultured CNS cells

\begin{tabular}{llll}
\hline Receptor & CNS cells & Species & Reference \\
\hline IL8R, CXCR-4, CCR-1, CX 3 CR-1 & Astrocytes & Human, mouse, rat & Tanabe et al, 1997; Jiang et al, 1998; Heesen 1997 \\
IL8R, CXCR-4, CCR-3, CCR-5, CX ${ }_{3}$ CR-1 & Microglia & Human, mouse, rat & He et al, 1996; Tanabe et al, 1997; Jiang et al, 1998 \\
CXCR-2, CXCR-4, CCR-1, CCR-5 & Neurons & Human & Hesselgesser et al, 1997 \\
\hline
\end{tabular}




\section{References}

Asensio V, Campbell I (1997). Chemokine gene expression in the brains of mice with lymphocytic choriomeningitis. J Virol 71: 7832-7840.

Baggiolini M, Dewald B, Moser B (1997). Human chemokines: An update. Annu Rev Immunol 15: $675-705$.

Barnes D, Huston M, Holmes R, Benveniste E, Yong V, Scholz P, Perez H (1996). Induction of RANTES expression by astrocytes and astrocytoma cell lines. J Neuroimmunol 71: 207-214.

Bazan JF, Bacon KB, Hardiman G, Wang W, Soo K, Rossi D, Greaves DR, Zlotnik A, Schall TJ (1997). A new class of membrane-bound chemokine with a CX3C motif. Nature 385: 640-644.

Berman J, Guida M, Warren J, Amat J, Brosnan C (1996). Localization of monocyte chemoattractant peptide-1 expression on the central nervous system in experimental autoimmune encephalomyelitis and trauma in the rat. I Immunol 156: $3017-3023$.

Bourdoulous S, Bensaid A, Martinez D, Sheikboudou C, Trap I, Strosberg A, Couraud P (1995). Infection of bovine brain microvessel endothelial cells with Cowdria ruminantium elicits IL-1 beta, -6 , and -8 mRNA production and expression of an unusual MHC class II DQ alpha transcript. J Immunol 154: 4032-4038.

Calvo C, Yoshimura T, Gelman M, Mallat M (1996). Production of monocyte chemotactic protein-1 by rat brain macrophages. Eur J Neurosci 8: 1725-1734.

Cole K, Strick C, Loetscher M, Paradis T, Ogborne K, Gladue R, Lin W, Boyd J, Moser B, Wood D, Sahagan $B$, Neote K (1998). Interferon inducible T-cell alpha chemoattractant (I-TAC); a novel non-ELR CXC chemokine with potent activity on activated T-cells through selective high affinity binding to CXCR3. J Exp Med, In press.

Combadiere C, Ahuja SK, Murphy PM (1995). Cloning, chromosomal localization, and RNA expression of a human beta chemokine receptor-like gene. DNA Cell Biol 14: 673-680.

Conant K, Garzino-Demo A, Nath A, McArthur JC, Halliday W, Power C, Gallo RC, Major EO (1998). Induction of monocyte chemoattractant protein-1 in HIV-1 Tat-stimulated astrocytes and elevation in AIDS dementia. Proc Natl Acad Sci USA 95: 3117-3121.

Ehrlich L, Hu S, Sheng W, Suttion R, Rockswold G, Peterson P, Chao C (1998). Cytokine regulation of human microglial cell IL-8 production. J Immunol 160: $1944-1948$.

Fisher S, Vanguri P, Shin H, Shin M (1995). Regulatory mechanisms of MuRantes and CRG-2 chemokine gene induction in central nervous system glial cells by virus. Brain Behav Immun 9: $331-344$.

Fuentes M, Durham S, Swerdel M, Lewin A, Barton D, Megill J, Bravo R, Lira S (1995). Controlled recruitment of monocytes/macrophages to specific organs via transgenic expression of MCP-1. J Immunol 155: $5769-5776$

Ghirnikar CS, Lee YL, He TR, Eng LF (1996). Chemokine expression in rat stab wound brain injury. I Neurosci Res 46: $727-733$.

Gitter B, Cox L, Rydel R, May P (1995). Amyloid beta peptide potentiates cytokine secretion by interleukin-1 beta-activated human astrocytoma cells. Proc Natl Acad Sci USA 92: 10738-10741.
Glabinski A, Tani M, Strieter R, Tuohy V, Ransohoff R (1997). Synchronous synthesis of $\alpha$ - and $\beta$-chemokines by cells of diverse lineage in the central nervous system of mice with relapses of experimental autoimmune encephalomyelitis. Am J Pathol 150: 617630.

Glabinksi A, Tani M, Tuohy VK, Tuthill RJ, Ransohoff RM (1996a). Central nervous system chemokine gene expression follows leukocyte entry in acute murine experimental autoimmune encephalomyelitis. Brain Behav Immun 9: $315-330$.

Glabinski AR, Tani M, Balasingam V, Yong VW, Ransohoff RM (1996b). Chemokine monocyte chemoattractant protein-1 (MCP-1) is expressed by astrocytes after mechanical injury to the brain. J Immunol 156: $4363-4368$.

Godiska R, Chantry D, Dietsch G, Gray P (1995). Chemokine expression in murine experimental autoimmune encephalomyelitis. J Neuroimmunol 58: $167-176$.

Gourmala NG, Buttini M, Limonta S, Sauter A, Boddeke HW (1997). Differential and time-dependent expression of monocyte chemoattractant protein-1 mRNA by astrocytes and macrophages in rat brain: effects of ischemia and peripheral lipopolysaccharide administration. J Neuroimmunol 74: 35-44.

Grzybicki D, Moore S, Schelper R, Glabinski A, Ransohoff R, Murphy S (1998). Expression of monocyte chemoattractant protein (MCP-1) and nitric oxide synthase-2 following cerebral trauma. Acta Neuropathol 95: $98-103$.

Halford W, Gebhardt B, Carr D (1996). Persistent cytokine expression in trigeminal ganglion latently infected with herpes simplex virus type 1. I Immunol 157: $3542-3549$

Harrison J, Barber C, Lynch K. (1994). cDNA cloning of a G-protein coupled receptor expressed in rat spinal cord and brain related to chemokine receptors. Neurosci Lett 169: 85-89.

Hausmann E, Berman N, Wang Y-Y, Meara J, Wood G, Klein R (1998). Selective chemokine mRNA expression following brain injury. Brain Res 788: 49-59.

Hayashi M, Luo Y, Laning J, Strieter RM, Dorf ME (1995). Production and function of monocyte chemoattractant protein-1 and other beta-chemokines in murine glial cells. J Neuroimmunol 60: 143-150.

He J, Chen Y, Farzan M, Choe H, Ohagen A, Gartner S, Busciglio J, Yan X, Hofmann W, Newman W, Mackay CR, Sodroski J, Gabuzda D (1996). CCR3 and CCR5 are co-receptors for HIV-1 infection of microglia. Nature 385: 645 .

Heesen M, Berman MA,Benson ID, Gerard C, Dorf ME (1996a). Cloning of the mouse fusin gene, homologue to a human HIV-1 co-factor. J Immunol 157: 5455.

Heesen M, Berman MA, Hopken UE, Gerard NP, Dorf ME (1997). Alternate splicing of mouse fusin/CXC chemokine receptor-4: stromal cell-derived factor1alpha is a ligand for both CXC chemokine receptor4 isoforms. I Immunol 158: 3561-3564. 
Heesen M, Tanabe S, Berman MA, Yoshizawa I, Luo Y, Kim RJ, Post TW, Gerard C, Dorf ME (1996b). Mouse astrocytes respond to the chemokines MCP-1 and KC, but reverse transcriptase-polymerase chain reaction does not detect mRNA for the KC or new MCP-1 receptor. J Neurosci Res 45: 382-391.

Hesselgesser J, Halks-Miller M, DelVecchio V, Peiper SC, Hoxie J, Kolson DL, Taub D, Horuk R (1997). CD4independent association between HIV-1 gp120 and CXCR4: functional chemokine receptors are expressed in human neurons. Curr Biol 7: 112-121.

Horuk R, Martin A, Hesselgesser J, Hadley T, Lu ZH, Wang ZX, Peiper SC (1996). The Duffy antigen receptor for chemokines: structural analysis and expression in the brain. J Leukoc Biol 59: 29-38.

Horuk R, Martin AW, Wang Z, Schweitzer L, Gerassimides A, Guo H, Lu Z, Hesselgesser J, Perez HD, Kim J, Parker J, Hadley TJ, Peiper SC (1997). Expression of chemokine receptors by subsets of neurons in the central nervous system. I Immunol 158: 2882-2890.

Hulkower K, Brosnan CF, Aquino DA, Cammer W, Kulshrestha S, Guida MP, Rapoport DA, Berman JW (1993). Expression of CSF-1, C-fms, and MCP-1 in the central nervous system of rats with experimental allergic encephalomyelitis. J Immunol 150: 25252533.

Hurwitz A, Lyman W, Berman J (1995). Tumor necrosis factor $\alpha$ and transforming growth factor $\beta$ upregulate astrocyte expression of monocyte chemoattractant protein-1. J Neuroimmunol 57: 193-198.

Hvas J, McLean C, Justesen J, Kannourakis G, Steinman L, Oksenberg J, Bernard C (1997). Perivascular T-cells express the proinflammatory chemokine RANTES mRNA in multiple sclerosis lesions. Scand J Immunol 46: $195-203$.

Imai $\mathrm{T}$, Hieshima $\mathrm{K}$, Haskell $\mathrm{C}$, Baba $\mathrm{M}$, Nagira $\mathrm{M}$, Nishimura M, Kalizaki M, Takagi S, Nomiyama $H$, Schall TJ, Yoshie O (1997). Identification and molecular characterization of fractalkine receptor CX3CR1, which mediates both leukocyte migration and adhesion. Cell 91: 521-530.

Ishizuka K, Kimura T, Igata-yi R, Katsugari S, Takamatsu J, Miyakawa T (1997). Identification of monocyte chemoattractant protein-1 in senile plaques and reactive microglia of Alzheimer's disease. Psychiatry Clin Neurosci 51: 135-138.

Ivacko J, Szaflarski J, Malinak C, Flory C, Warren J, Silverstein F (1997). Hypoxic-ischemic injury induces monocyte chemoattractant protein-1 expression in neonatal rat brain. J Cereb Blood Flow Metab 17: $759-770$.

Jiang Y, Salafranca M, Adhikari S, Xia Y, Feng L, Sonntag M, deFiebre C, Pennell N, Striet W, Harrison J (1998). Chemokine receptor expression in cultured glia and rat experimental allergic encephalomyelitis. $J$ Neuroimmunol, in press.

Kaiser E, Forster R, Wolf I, Ebensperger C, Kuehl WM, Lipp M (1993). The G protein-coupled receptor BLR1 is involved in murine $\mathrm{B}$ cell differentiation and is also expressed in neuronal tissues. Eur J Immunol 23: $2532-2539$.

Karpus WJ, Ransohoff RM (1998). Commentary: Chemokine regulation of experimental autoimmune encephalomyelitis: temporal and spatial exression patterns govern disease pathogenesis. J Immunol, Submitted.
Karpus WJ, Kennedy KJ, Lucchinetti CF, Bruck W, Rodriguez M, Lassmann H (1997). MIP-1 $\alpha$ and MCP1 differentially regulate acute and relapsing autoimmune encephalomyelitis as well as Th1/Th2 lymphocyte differentiation. J Leukoc Biol 62: 681687.

Karpus WJ, Lukas NW, McRae BL, Strieter RM, Kunkel SL, Miller SD (1995). An important role for the chemokine macrophage inflammatory protein- $1 \alpha$ in the pathogenesis of the T-cell-mediated autoimmune disease, experimental autoimmune encephalomyelitis. J Immunol 155: 5003-5010.

Kasahara T, Mukaida N, Yamashita K, Yagisawa H, Akahoshi T, Matsushima K (1991). IL-1 and TNFalpha induction of IL-8 and monocyte chemotactic and activating factor (MCAF) mRNA expression in a human astrocytoma cell line. Immunology 74: 60-67.

Kim JS, Gautam SC, Chopp M, Zaloga C, Jones ML, Ward PA, Welch KMA (1995). Expression of monocyte chemoattractant protein-1 and macrophage inflammatory protein-1 after focal cerebral ischemia in the rat. $J$ Neuroimmunol 56: 127-134.

Kossmann T, Stahel PF, Lenzlinger PM, Redl H, Dubs RW, Trentz O, Schlag G, Morganti-Kossmann MC (1997). Interleukin-8 released into the cerebrospinal fluid after brain injury is associated with blood-brain barrier dysfunction and nerve growth factor production. J Cereb Blood Flow Metab 17: 280-289.

Lane T, Asensio V, Yu N, Paoletti A, Campbell I, Buchmeier M (1998). Dynamic regulation of alphaand beta-chemokine expression in the central nervous system during mouse hepatitis virus-induced demyelinating disease. J Immunol 160: 970-978.

Lipovsky M, Gekker G, Hu S, Ehrlich L, Hoepelman A, Peterson P (1998). Cryptococcal glucuronoxylomannan induces interleukin (IL)-8 production by human microglia but inhibits neutrophil migration toward IL-8. I Infect dis 177: 260-263.

Lira S, Fuentes M, Strieter R, Durham S (1997). Transgenic methods to study chemokine function in lung and central nervous system. Met Enzymol 287: $304-318$

Littman D. (1998). In Keystone Conference on HIV pathogenesis and treatment. Park City, UT.

Liu T, Young PR, McDonnell PC, White RF, Barone FC, Feuerstein CZ. (1993). Cytokine-induced neutrophil chemoattractant mRNA expressed in cerebral ischemia. Neurosci Lett 164: 125-128.

Lokensgard J, Gekker G, Ehrlich L, Hu S, Chao C, Peterson P (1997). Proinflammatory cytokines inhibit HIV-1 (SF12) expression in acutely infected human brain cell cultures. J Immunol 158: 2449-2455.

Lopez-Cortes LF, Cruz-Ruiz M, Gomez-Mateos J, VicianaFernandez P, Martinez-Marcos FJ, Pachon J (1995). Interleukin-8 in cerebrospinal fluid from patients with meningitis of different etiologies: Its possible role as neutrophil chemotactic factor. J Infect dis 172: 581584.

Lou J, Ythier A, Burger D, Zheng L, Julliard P, Lucas R, Dayer J, Grau G (1997). Modulation of soluble and membrane-bound TNF-induced phenotypic and functional changes of human brain microvascular endothelial cells by recombinant TNF-binding protein 1. J Neuroimmunol 77: 107-115. 
McManus C, Brosnan C, Berman J (1998). Cytokine induction of MIP-1 alpha and MIP-1 beta in human fetal microglia. J Immunol 160: 1449-1455.

McTigue D, Tani M, Kravacic K, Chernosky A, Kelner G, Maciejewski D, Maki R, Ransohoff RM, Stokes B (1998). Selective chemokine mRNA accumulation in the rat spinal cord after contusion injury. J Neurosci Res, In press.

Meda L, Bernasconi S, Bonaiuto C, Sozzani S, Zhou D, Otvos LJ, mantovani A, Rossi F, Cassatella M (1996). Beta-amyloid (25-35) peptide and IFN-gamma synergistically induce the production of the chemotactic cytokine MCP-1/JE in monocytes and microglial cells. J Immunol 157: 1213-1218.

Miyagishi R, Kikuchi S, Fukazawa T, Tashiro K (1995). Macrophage inflammatory protein- $1 \alpha$ in the cerebrospinal fluid of patients with multiple sclerosis and other inflammatory neurological diseases. J Neurol Sci 129: $223-227$.

Morita M, Kasahara T, Mukaida N, Matsushima K, Nagashima T, Nishizawa M, Yoshida M (1993). Induction and regulation of IL-8 and MCAF production in human brain tumor cell lines and brain tumor tissues. Eur cytokine Netw 4: 351-358.

Murphy PM (1996). Chemokine receptors: structure, function and role in microbial pathogenesis. Cytok Growth Fact Rev 7: 47-64.

Nagasawa T, Nakajima T, Tachibana K, Iizasa H, Bleul CC, Yoshie O, Matsushima K, Yoshida N, Springer TA, Kishimoto $\mathrm{T}$ (1996). Molecular cloning and characterization of a murine pre-B-cell growth-stimulating factor/stromal cell-derived factor 1 receptor, a murine homolog of the human immunodeficiency virus 1 entry coreceptor fusin. Proc Natl Acad Sci USA 93: 14726 .

Nitta T, Allegretta M, Okumura K, Sato K, Steinman L (1992). Neoplastic and reactive human astrocytes express interleukin-8 gene. Neurosurgical Review 15: $203-207$.

Pan Y, Lloyd C, Zhou H, Dolich S, Deeds J, Gonzalo JA, Vath J, Gosselin M, Ma J, Dussault B, Woolf E, Alperin G, Culpepper J, Gutierrez-Ramos JC, Gearing D (1997). Neurotactin, a membrane-anchored chemokine upregulated in brain inflammation. Nature 387: $611-617$.

Peterson PK, Hu S, Salak-Johnson J, Molitor TW, Chao CC (1997). Differential production of and migratory response to beta chemokines by human microglia and astroyctes. J Infect Dis 175: 478-481.

Premack BA, Schall TJ (1996). Chemokine receptors: Gateways to inflammation and infection. Nature Med 2: $1174-1178$.

Rani M, Leaman D, Leung S, Foster G, Stark G, Ransohoff RM (1996). Characterization of $\beta$-R1, a gene that is selectively induced by IFN- $\beta$ compared with IFN- $\alpha$. J Biol Chem 271: 22878-22884.

Ransohoff R, Glabinski A, Tani M (1996). Chemokines in immune-mediated inflammation of the central nervous system. Cytokine Growth Factor Rev 7: 35-46.

Ransohoff RM, Hamilton TA, Tani M, Stoler MH, Shick HE, Major JA, Estes ML, Thomas DM, Tuohy VK (1993). Astrocyte expression of mRNA-encoding cytokines IP-10 and JE/MCP-1 in experimental autoimmune encephalomyelitis. FASEB J 7: 592-602.
Sasseville VG, Smith MM, Mackay CR, Pauley DR, Mansfield KG, Ringer DJ, Lackner AA (1996). Chemokine expression in simian immunodeficiency virusinduced AIDS encephalitis. Am J Pathol 149: 14591467.

Seebach J, Bartholdi D, Frei K, Spanaus K, Ferrero E, Widmer U, Isennann S, Streiter R, Schwab M, Pfister H, Fontana A (1995). Experimental Listeria meningoencephalitis: macrophage inflammatory protein-1a and 2 are produced intrathecally and mediate chemotactic activity in cerebrospinal fluid of infected mice. I Immunol 155: 4367-4375.

Simpson J, Newcombe J, Cuzner M, Woodroofe M (1998). Expression of monocyte chemoattractant protein-1 and other $\beta$-chemokines by resident and inflammatory cells in multiple sclerosis lesions. J Neuroimmunol, In Press.

Sopper S, Demuth M, Stahl-Hennig C, Hunsmann G, Plesker R, Coulibaly C, Czub S, Ceska M, Koutsilieri E, Riederer P, Brinkmann R, Katz M, ter Meulen v (1996). The effect of simian immunodeficiency virus infection in vitro and in vivo on the cytokine production of isolated microglia and peripheral macrophages from rhesus monkey. Virology 220: $320-329$

Spanaus KS, Nadal D, Pfister HW, Seebach J, Widmer U, Frei K, Gloor S, Fontana A (1997). C-X-C and C-C chemokines are expressed in the cerebrospinal fluid in bacterial meningitis and mediate chemotactic activity on peripheral blood-derived polymorphonuclear and mononuclear cells in vitro. J Immunol 158: 1956-1964.

Sprenger H, Rosler A, Tonn P, Braune HJ, Hufmann G, Gemsa D (1996). Chemokines in the cerebrospinal fluid of patients with meningitis. Clin Immunol Immunopathol 80: 155-161.

Sun D, Hu X, Liu X, Whitaker JN, Walker WS (1997). Expression of chemokine genes in rat glial cells: the effect of myelin basic protein-reactive encephalitogenic T-cells. J Neurosci Res 48: 192-200.

Takami S, Nishikawa H, Minami M, Nishiyori A, Sato M, Akaike A, Satoh M (1997). Induction of macrophage inflammatory protein MIP-1 alpha mRNA on glial cells after focal cerebral ischemia in the rat. Neurosci Lett 227: $173-176$.

Tanabe S, Heesen M, Berman MA, Fischer MB, Yoshizawa I, Luo Y, Dorf ME (1997). Murine astrocytes express a functional chemokine receptor. $J$ Neurosci 17: $6522-6528$

Tani M, Fuentes ME, Peterson JW, Trapp BD, Durham SK, Loy JK, Bravo R, Ransohoff RM, Lira SA (1996a). Neutrophil infiltration, glial reaction and neurological disease in transgenic mice expressing the chemokine N51/KC in oligodendrocytes. J Clin Invest 98: 529539.

Tani M, Glabinski AR, Tuohy VK, Stoler MH, Estes ML, Ransohoff RM (1996b). In situ hybridization analysis of glial fibrillary acidic protein mRNA reveals evidence of biphasic astrocyte activation during acute experimental autoimmune encephalomyelitis. Am J Pathol 148: 889-896. 
Van Meir E, Ceska M, Effenberger F, Waltz A, Grouzmann E, Desbaillets I, Frei K, Fontana A, de Tribolet N (1992). Interleukin-8 is produced in neoplastic and infectious diseases of the human central nervous system. Cancer Res 52: 4297-4305.

Wang X, Yue T-L, Barone FC, Feuerstein CZ (1995). Monocyte chemoattractant protein-1 messenger RNA expression in rat ischemic cortex. Stroke 26: 661666.

Westmoreland SV, Rottman JB, Williamd KC, Lackner AA, Sasseville VG (1998). Chemokine receptor expression on resident and inflammatory cells in the brain of macaques with simian immunodeficiency virus encephalitis. Am J Pathol 152: 659-665.

Wong M-L, Xin WW, Duman RS (1996). Rat LCR1: cloning and cellular distribution of a putative chemokine receptor in brain. Mol Psychiatry 1: $133-140$.

Xia M, Qin S, McNamara M, Mackay, Hyman B (1997). Interleukin-8 receptor B immunoreactivity in brain and neuritic plaques of Alzheimer's disease. Am J Pathol 150: $1267-1274$.

Yamasaki Y, Matsuo Y, Matsuura N, Onodera H, Itoyama Y, Kogure K (1995). Transient increase of cytokineinduced neutrophil chemoattractant, a member of the interleukin-8 family, in ischemic brain areas after focal ischemia in rats. Stroke 26: $318-323$.
Yoshimoto T, Houkin K, Tada M, Abe H (1997). Induction of cytokines, chemokines and adhesion molecule mRNA in a rat forebrain reperfusion model. Acta Neuropathol 93: 154-158.

Yoshimura T, Robinson EA, Tanaka S, Appella E, Leonard EJ (1989). Purification and amino acid analysis of two human monocyte chemoattractants produced by phytohemagglutinin-stimulated human blood mononuclear leukocytes. J Immunol 142: 1956-1962.

Zach O, Bauer HC, Richter K, Webersinke G, Tontsch S, Bauer H (1997). Expression of a chemotactic cytokine (MCP-1) in cerebral capillary endothelial cells in vitro. Endothelium 5: 143-153.

Zhou ZH, Chaturvedi P, Han Y-L, Aras S, Li Y-S, Kolattukudy PE, Ping D, Boss JM, Ransohoff RM (1998). Interferon-g induction of the human monocyte chemoattractant (hMCP)-1 gene in astrocytoma cells: functional interaction between a gamma activated site (GAS) and GC-rich element. I Immunol 160: 39083916. 